\title{
IMPACT OF TAX IMPOSITION ON ELECTRONIC COMMERCE (E-COMMERCE) TRANSACTIONS
}

\author{
Nicky Amanati Laily Rizkyana \\ Magister Kenotariatan, Fakultas Hukum, Universitas Airlangga \\ e-mail:nickyamanati@yahoo.com \\ Sofa Azammusyahada \\ Magister Kenotariatan, Fakultas Hukum, Universitas Airlangga \\ e-mail: shofaazam@gmail.com \\ Khilaima Faillafah \\ Magister Kenotariatan, Fakultas Hukum, Universitas Airlangga \\ e-mail: khilaimafaillafah@hotmail.com
}

\begin{abstract}
ABSTRAK
Perkembangan teknologi mendorong manusia untuk terus melakukan pembaharuan dan inovasi dalam melakukan suatu kegiatan, khususnya dalam kegiatan bisnis. Para pengusaha secara pribadi merupakan wajib pajak, biasanya dapat dibuktikan dengan kepemilikan suata usaha yang wujudnya nyata, atau memiliki toko yang nyata. Perkembangan dunia teknologi seperti saat ini mendorong masyarakat untuk menjual barang dagangannya tidak hanya di dalam bentuk offline, tetapi dalam wujud online pula. Pembelanjaan online ini pada akhirnya menimbulkan berkembangnya secara pesat market place yang merupakan usaha start up yang saling mempertemukan para penjual dan pembeli secara online. Hal tersebut pada akhirnya mendorong negara untuk membuat suatu aturan yang mewajibkan para pengusaha e-commerce ini untuk menjadi wajib pajak, tujuannya untuk didapatkannya pemasukan negara sebagai salah satu sumber pendapatan negara.
\end{abstract}

Kata Kunci: E-commerce; Pajak; Wajib Pajak

\section{ABSTRACT}

The growth of technology pushes people to continue updating and innovating every aspects of life, especially business matter. Entrepreneur people are personally taxpayer, usually proved by owning a a certain type of business which form in goods or store. The growth of technologies nowadays pushes people to sell their goods not only via offline but also via online. This online shopping eventually results in a rapid development of market place such as start up business that brings together sellers and buyers online. This eventually prompted the state to make a regulation that requires e-commerce entrepreneurs to become taxpayers. The goal is to get state income as one of the country's revenue sources.

Keywords: E-commerce; Tax; Taxpayer

\section{FOREWARD}

Science and technology are growing rapidly, so that human needs continue to increase. This need covers all aspects of people's lives in Indonesia in this globalization era. One of them is in the economic field. The following are the impacts of development in the economic field:

a. Higher economic growth;

\footnotetext{
${ }^{1}$ Andy Hartanto. (2015). Hukum Jaminan dan Kepailitan. Surabaya: Laksbang Justitia, h. 5.
} 
b. The occurrence of industrialization;

c. Increased productivity;

d. Business competition both from within and outside the country;

e. Large-scale investment and reinvestment that can increase economic productivity;

f. Competition in the world of work that requires work to always enhance their skills and knowledge.

Economic growth is in line with technological developments that can affect people's life patterns. For example, before trading was done face to face, now it can be done online. ${ }^{2}$ Changes in the lifestyle of this community are considered more effective and efficient to do, because it does not require much time to do the activity. Similar to the trading system, there are currently many online trading applications offered. Electronic trading is called E-commerce which is an extension of Electronic Commerce which means trading is carried out electronically. E-commerce means electronic commerce which includes the process of buying, selling, transferring, or exchanging products, services, or information through computer networks, including the Internet. ${ }^{3}$

E-commerce is the activity of buying and selling service goods or the transmission of data funds through electronic networks, especially the internet. But now e-commerce has undergone various developments, ranging from functions to various types of e-commerce. There are at least seven basic types of e-commerce or e-commerce business forms with different characteristics: ${ }^{4}$

1. Business-to-Business (B2B), B2B e-commerce includes all electronic transactions of goods or services carried out between companies. Traditional producers and traders usually use this type of e-commerce.

2. Business-to-Consumer (B2C), B2C is a type of e-commerce between companies and end consumers. This is in accordance with the retail part of e-commerce which is usually operated

\footnotetext{
${ }^{2}$ Fani Martiawan Kumara Putra. (2019). "Pendaftaran Online Jaminan Fidusia Sebagai Suatu Fasilitas Kredit Dengan Potensi Lemahnya Perlindungan Kreditor". Perspektif. Vol 24 No. 2 Tahun 2019, h. 95-105.

${ }^{3}$ Abdul Halim Barkatullah. (2006). Bisnis E-Commerce. Yogyakarta: Pustaka Pelajar, h. 45.

${ }^{4}$ Purbo Onno W. dan Aang Arif Wahyudi. (2001). Mengenal E-Commerce. Jakarta: Elex Media Komputindo, h. 35.
}

by traditional retail trade. This type can be easier and more dynamic, but also more spread unevenly or even stalled.

3. Consumer-to-Consumer (C2C), C2C is a type of e-commerce that includes all electronic transactions of goods or services between consumers. Generally these transactions are carried out through third parties who provide online platforms to carry out these transactions.

4. Consumer-to-Business (C2B), C2B is a type of e-commerce with a complete reversal of traditional exchange or buying and selling transactions. This type of e-commerce is very common in multi-resource based projects. A large group of individuals provides their services or products for companies seeking those services or products.

5. Business-to-Administration (B2A), B2A is a type of e-commerce that includes all transactions conducted online between companies and public administration. This type of e-commerce involves many services, especially in fields such as fiscal, social security, employment, legal documents and registers, and others. This type of e-commerce has increased in recent years with investments made through e-government.

6. Consumer-to-Administration (C2A), Type C2A includes all electronic transactions carried out between individuals and public administration. Examples of areas that use this type of e-commerce are: Education, distance learning processes, social security, payments, tax filing, tax payments, health, information about illness, payment for health services and others.

7. Online-to-Offline (O2O), O2O is a type of e-commerce that attracts customers from online channels to physical stores. O2O identifies customers in online fields such as email and internet advertising, then uses various tools and approaches to attract customers to leave the online scope. For example, a fitness center will not be able to be set up in the living room of your house, but by using $\mathrm{O} 2 \mathrm{O}$ services provided by companies such as Groupon Inc., the fitness center can channel its offline business online.

E-commerce which is a form of electronic commerce is becoming a trend in trade in Indonesia today. So it is not only electronic trading but is 
accompanied by electronic payments that we know as Financial Technology (hereinafter abbreviated as fintech). Fintech is an innovation in the field of financial services. Fintech influences people's transaction habits to be more practical and effective. Fintech also helps people to more easily get access to financial products and increase financial literacy. Bank Indonesia clarifies four types of fintech: ${ }^{5}$

1. Crowdfunding and Peer to Peer Lending, fintech is useful as a mediation that finds investors with capital seekers, like a marketplace in e-commerce terms. Crowdfunding (mass financing or joint-based financing) and peer to peer (hereinafter abbreviated to P2P Lending) are overseen by the Financial Services Authority. Crowdfunding is very useful for fundraising such as to fund a work, help disaster victims and others. With fintech, fundraising can be done online, so that raising will be easier and more efficient. P2P Lending is a fintech service that really helps MSMEs so that they can borrow funds easily even though they don't have an account at a bank. Capital is certainly a very significant issue of course to develop businesses and meet the financial needs of the community.

2. Market Aggregator, in this classification fintech will act as a comparison of financial products, where the fintech will collect and collect financial data for reference by users. This classification can also be referred to as the comparison site or financial aggregator. For example, if a consumer wants to choose a Public Housing Credit product (hereinafter abbreviated as KPR), the fintech platform will adjust consumers' personal financial data and provide a choice of KPR product in accordance with the personal data entered. This choice will be given in accordance with the wishes and financial capabilities and preferences of consumers.

3. Risk and Investment Management, the concept offered by Fintech in this classification has functions such as a digital financial planner. Users will be helped to get the most suitable investment products according to the given preferences. In addition to risk management

${ }^{5}$ Diakses melalui https://www.finansialku.com/definisifintech-adalah/, pada tanggal 25 Februari 2019, Pukul 16.20 WIB. and investment, in this classification, there is also asset management, where Fintech will assist the operation of a business so that it is more practical. Fintech which is engaged in financial planning is also classified in this type of classification.

4. Payment, Settlement and Clearing, Fintech types incorporated in this classification are payments (payments) such as payment gateways and e-wallets. This classification is supervised by BI (Bank Indonesia) because this payment process also includes the velocity of money which will later be the responsibility of Bank Indonesia. Electronic money is money that is packaged in digital form where the money can be a means of payment in general, for shopping, paying bills and others just by going through an application. Fintech which has sprung up in Indonesia has become one of the alternatives in terms of online-based payments. One type is an online credit system called $P 2 P$ Lending. P2P Lending is present as one example of the type of E-Commerce C2C type. P2P Lending is also legally regulated in Financial Services Authority Regulation Number 77/POJK.01/2016 Regarding Information Technology Based Borrowing and Lending Services (hereinafter referred to as POJK 77/POJK.01/2016) as the legal basis for lending and borrowing systems with the usual electronic system called Financial technology. P2P Lending, which has just started operating in 2016, is already in demand and many PT-based companies have joined in. One of the leading companies is PT. Investree, Amarta. co.id, Koinworks, etc. P2P Lending Service is a company that brings together lenders (investors) with loan seekers (borrowers). There are 73 P2P Lending Services registered until September 2018 and 67 of them have permission. ${ }^{6}$

$\mathrm{P} 2 \mathrm{P}$ Lending is present in the community as a manifestation that credit application is not only done if someone has an account at a bank, but can also be done by someone without first having an account. The offer given by P2P Lending is partly because the digital transaction system is seen as providing more convenience, speed, practicality because it can be done anytime and anywhere. In addition to the superiority of P2P Lending also made a new

6 "Fintech Terdaftar", diakses pada www.ojk.go.id, pada 16 Februari 2019 pukul 17.28 WIB. 
breakthrough by verifying customers without faceto-face and paperless or paperless which cannot be done by Conventional Banks. Besides the advantages that arise there are also some weaknesses of this P2P Lending online business, which is sometimes people still doubt whether this service is true and trustworthy or not. ${ }^{7}$

It is undeniable that e-commerce companies are one of the fast growing industrial sectors in Indonesia. In general, e-commerce is an electronic sale and purchase transaction via the internet. However, over time the definition of e-commerce is increasingly widespread. E-commerce also means not only sales and purchases via the internet but also includes online customer service and exchange of business documents. Indonesia itself ranks 4th largest in the world with a population of 264 million inhabitants that holds a large digital economic potential. This potential is predicted to grow as a whole in the next few years. This is in line with the increasing number of people who use mobile phones to shop online.

Start-up businesses, one of which is a form of electronic commerce makes business people to flock to do the business. With the implementation of the tax on electronic businesses, the business actors partly considered that this business was a start-up effort so that there had to be encouragement from the state as one of the efforts made by several start-ups to reduce unemployment. With electronic trading, it is expected that novice business people will not be burdened by taxes, it is enough that they are themselves subject to tax. Because e-commerce businesses are increasingly mushrooming, pushing the government to impose taxes like other companies.

On January 11, 2019, the government issued the e-commerce Tax Treatment Regulations. This regulation was issued to provide certainty related to the taxation aspects for business people who carry out business activities or sales through electronic systems. This regulation was passed by the government through the Minister of Finance having issued Regulation of the Minister of Finance Number 210/PMK.010/2018 concerning Tax Treatment of

7 "Keuntungan dan Kerugian Peer To Peer Lending", Diakses melalui https://www.kompasiana.com/ graciamoudyvallentine 7708/5b4daeab5a676f1d490f6d02/peerto-peer-p2p-lending?page =all, pada tanggal 25 Februari 2019, pada pukul 16.34 WIB.
Trade Transactions through the Electronic System (hereinafter referred to as PMK 210/PMK.010/2018).

\section{PROBLEM FORMULATION}

Characteristics of e-commerce to be made a taxpayer in Indonesia, and the imposition of taxation on e-commerce businesses encourage awareness in paying taxes.

\section{RESEARCH METHODS}

This research uses the type of doctrinal research, this research produces a systematic explanation of the legal rules governing a particular legal category. Besides doctrinal research aims also as an academic necessity that is researchers positioned as a neutral party and the target audience is academics and practitioners. This research used statute approach and conceptual approach

\section{DISCUSSION}

The journey of fintech in Indonesia since 2016 underwent a very rapid change. This is inseparable from the support of government policies that have provided space for industries that are relatively new in this country. The journey is inseparable from the increase in smartphone users in Indonesia. E-marketers estimate that in 2018 there will be more than 100 million active smartphone users in Indonesia. With that number, Indonesia will become the country with the fourth largest active smartphone user in the world after China, India, and America. ${ }^{8}$

The majority of smartphone users can also be said as internet users. With a uniform internet coverage, all levels of society can utilize internet services through their cellphones. All information and business transactions are simply done by touching the smartphone screen only. In addition to buying and selling goods, the public can also use smartphones to access financial products without having to come to the bank.

The increasing use of the internet has contributed to the growth of fintech. Evidently the number of fintech startups that grew in Indonesia. According to the Indonesian Fintech Association, of the 140 fintech players, 43 percent focus on the payment

\footnotetext{
8 "Fintech terdaftar" www.ojk.go.id (online), 4 Desember
} 2018. 
sector. So it greatly helps the expansion of banking services in digital-based types of financial services.

P2P Lending in this case Investree which was present in 2016 is considered to have contributed to the development and national economy. The community can apply for a loan because it is supported by fellow users in the P2P Lending system, namely from the community itself or in this case the lender. P2P Lending has also been regulated by POJK 77/POJK.01/2016, which regulates legal entities, capital, loan maximum limits, the form of agreements used, to regulate borrowers and lenders from individuals to business entities. The point is to oversee the implementation of a healthy business and be able to protect consumers and businesses.

At present only 36 percent of adults have a formal financial institution account. The penetration of bank branches per 100,000 population is only $1 / 6$ of the penetration in European countries. The Indonesia Fintech Report 2016, published by Daily Social, said that as many as 49 million SMEs were not yet bankable, so there was a potential of Rp 989 trillion in gap financing that could be worked on. Besides P2P Lending is still under Rp 150 billion. The small share of credit in the banking sector, which is 34.77 percent of GDP, also shows a large market potential that can be worked on by fintech through P2P Lending, without having to erode the bank's market share. ${ }^{9}$

In the practice of fintech, lending and borrowing activities at P2P Lending are here to fill gaps in banking services that are deemed inefficient and ineffective. So that P2P Lending in this case Investree comes with excellence which is done online, without face to face. In addition, to get a loan, the debtor does not need to guarantee anything. The development of fintech has also led to changes in the financial industry, from the traditional system that is filled with banking (bank driven) to financial technology (consumer driven), this allows more players to emerge in the financial sector.

After the presence of POJK 77/POJK.01/2016, the growth of fintech services continues to increase until it reaches $78 \%$. Similarly, the level

\footnotetext{
9 "E-Commerce in Asia: Bracing for Digital Disruption", diakses melalui https://www.dbs.com/spark/index/id_id/dbs-yesasset/files/(Riset\%201)\%20Mendorong\%20Pengembangan\%20 Ekonomi\%20Digital\%20di\%20Luar\%20Jawa, dikutip pada tanggal 18 Februari 2019, pada pukul 06.02 WIB.
}

of financial literacy is getting better, especially in the millennial market. The more complete thanks to good collaboration between stakeholders to strengthen the growth of fintech in the country. It is inseparable from the strengthening of consolidation and the synergy of business actors to integrate their respective potentials. While business players in the P2P Lending service sector at the beginning of the year still recorded a growth of around $15 \%$ and then surged to around $32 \%$ at the end of last year. Data released by the FSA regarding the P2P lending system shows that the number of transactions has reached Rp.2.2 billion. $^{10}$

The ease of fintech in the era of technology as it is today, does not necessarily provide convenience for all parties. Areas not yet reached by the internet are still impossible to access this fintech. Fintech will be one of the solutions for someone to get credit, if it is felt that banking is quite difficult and cannot be reached easily so it is not effective and efficient enough. The great potential of fintech is also related to the market share of young people who are accustomed to technology, because at this young age the term money for technology is very easily accessible. ${ }^{11}$

This online fund granting service is indeed something new under the rules or regulations of POJK Number 77/01/2016 concerning Information Technology Based Money Lending and Borrowing Services. Based on Article 1 number 6 POJK Number 77/POJK.01/2016 it is said that lending and borrowing institutions based on information technology must be in the form of legal entities. In Article 2 of the POJK, the types of legal entity explained include the form of a limited liability company. Providers in the form of limited liability companies can be owned by Indonesian citizens and/or Indonesian legal materials and/or foreign citizens and/or foreign legal entities, this is explained in Explanation of Article 3 POJK Number 77/POJK.01/2016.

Further explanation is explained in Article 3 which explains that what is meant by Indonesian legal entities includes but is not limited to the central

10 ibid.

11 "Pangsa Pasar Fintech". www.cnbcindonesia.com (online). 3 Desember 2018. https://www.cnbcindonesia.com/ fintech/20180113160215-40-1387/milenial-pasar-terbesarfintech. 
government, regional governments, foundations or limited liability companies. The explanation in Article 3 of the Regulation of the Financial Services Authority Number 77/POJK.01/2016 only regulates the ownership and establishment of loan-borrowing services to borrow technology-based money in the form of a limited liability company. While the ownership and establishment of the organizer of a limited liability company is possible to involve foreign parties. So that makes OJK explicitly regulate that online-based lending and borrowing services that are licensed by OJK are including a maximum of $85 \%$ ownership (eighty-five percent).

Pursuant to Article 6 paragraph 1 POJK No. $77 / 01 / 2016$ it is explained that the organizer is required to meet the maximum lending limit requirement for each borrower of funds to the recipient of the guarantee and this special provision sets a maximum figure of $\mathrm{Rp} 2,000,000,000$ (two billion rupiah). However, based on Article 6 in conjunction with Article 55 of the OJK Law, it can be reviewed by the OJK as the supervisor.

The form of supervision carried out by the OJK on technology-based lending and borrowing services is regulated in Supervision of banks in Indonesia no longer carried out by Bank Indonesia, bearing in mind that the OJK has the function of organizing an integrated regulation and supervision system in all sectors of all activities in the financial services sector written. This form of supervision is carried out by OJK in a manner regulated in the provisions of Article 40 POJK Number 77/POJK.01/2016, namely:

1. The organizer must report electronically every month to the FSA in the event that the plaintiff's complaint is accompanied by no details of the intended court settlement;

2. Organizers who have obtained licenses are required to submit periodic reports in the form of monthly reports and electrical engineering reports to OJK;

3. After receiving the various reports, OJK will carry out further supervision of the organizers of the prohibited actions in carrying out a business activity. This type of prohibition is regulated in Article 43 No. 77/POJK.01/2016 which reads:

a. Prohibition to carry out activities other than those of the Provider which are regulated in this OJK regulation; b. Provide guarantees in all its forms for the fulfillment of other parties' obligations

c. Issued debt securities;

d. Provide recommendations to users;

e. Publish fictitious and/or encouraging information;

f. Offering service to users and/or the public through personal communication facilities without the consent of the user; and

g. Charge users any fees for filing complaints. Therefore, if the party violates one of the prohibition provisions above, the organizer will be subject to sanctions in accordance with Article 47 POJK/77/01/2016, in this case the FSA has the right to provide a series of administrative sanctions against the organizer.

The characteristics of P2P Lending in Indonesia are regulated in Bank Indonesia Regulation Number 19/12/PBI/2017 concerning the Implementation of Financial Technology in Article 3 paragraph (1) and paragraph (2), as follows:

Article 3 paragraph (1) Implementation of Financial Technology is categorized into: a. Payment system; b. Market supporters; c. Investment management and risk management; d. Loans, financing and capital supply; and e. Other financial services.

Article 3 paragraph (2) Financial Technology as referred to in paragraph (1) has criteria: a. Is innovative; b. Can have an impact on existing products, services, technology and/or financial business models; c. Can provide benefits to the community; d. Can be widely used; and e. Other criteria determined by Bank Indonesia.

One of the criteria set by Bank Indonesia is the Regulatory Sandbox which is a safe limited trial space for testing Financial Technology Providers and their products, services, technology, and/or business models. So after registering with the Indonesian bank, a trial is immediately conducted, this trial is useful so that the Indonesian bank knows whether this fintech feasible is allowed to be used as a P2P Lending product. ${ }^{12}$

The regulatory sandbox approach will be an instrument to test business models, products, services and technologies for not only innovation startups or

${ }^{12}$ Mudakir Iskandarsyah. (2018). Hukum Bisnis Online Era Digital. Jakarta Barat: Campustaka, h. 87. 
startups engaged in the fintech field, but also for financial service institutions such as banks that innovate business processes. This approach was chosen because the rapid development of digital technology cannot be matched by the speed of rule making. ${ }^{13}$ Regulatory sandbox has another name as a laboratory test. Where, before a business idea from the fintech platform is operational or launched into the market, it must first go through a trial phase, before getting permission. ${ }^{14}$

But there are also some characteristics of $\mathrm{P} 2 \mathrm{P}$ Lending that can be compared with the Credit Online System, among others:

1. Legal relationship

Legal Relationship is an engagement that produces legal consequences. Legal Relationship in P2P Lending is a relationship between service providers in this case Investree and the lender, the Bank, with an agreement. The legal relationship is to establish cooperation in advance with other banks in order to make the bank a party that acts as a lender or will be a potential lender. Because Investree that uses this P2P Lending system is in fact only a medium that brings together those who need loans and who will provide loans.

This legal relationship also occurs because P2P Lending in this case Investree is not an Intermediary Institution or Institution that is allowed to collect and distribute public funds. In accordance with Article 1 number 2 jo Article 16 of the Banking Law. Intermediary institutions or fund raising are the main functions of national banking, namely to collect and distribute funds that are only allowed by financial institutions, while Investree is included in Non-Bank Financial Institutions.

So that the Legal Relationship between Investree and banks that have established cooperation is to anticipate actions that deviate from Article 1 number 2 in conjunction with Article 16 of the Banking Law. ${ }^{15}$

But there are also P2P Lending Services that can be said to be an Intermediary Institution

13 ibid.

14 ibid., h. 89.

${ }^{15}$ Airin. (2017). "Perbedaan Karakteristik Layanan Pinjam Meminjam Uang Berbasis Teknologi Informasi (Peer to Peer Lending) denganPerbankan". Skripsi. Surabaya: Program Sarjana, UniversitasAirlangga, h. 25. namely only one system also collects and distributes funds to the public.

2. Functions

As an online credit service provider, $\mathrm{P} 2 \mathrm{P}$ Lending has different functions than the online credit system in the banking system. Among them P2P Lending has the following functions: ${ }^{16}$

1) $\mathrm{P} 2 \mathrm{P}$ Lending which is present in this Online Platform provides a new facility, namely by providing easy access to borrowing and borrowing funds. The convenience offered by P2P Lending can be accessed through applications and websites that are open for 24 hours.

2) As Quick Funding, P2P Lending offers a process of disbursing funds that is relatively faster than bank loans in general. The bank lending process will be replaced, because in the P2P Lending system the process of disbursing funds only takes a few days.

3) Using the 3C Principle in the credit application process, In contrast to national banks which must adopt the $5 \mathrm{C}$ principle. The process of granting credit to prospective customers by P2P Lending only uses 3 principles, namely: ${ }^{17}$

- Character: An assessment of this character is carried out to determine the level of honesty, integrity, and the willingness of the prospective debtor to fulfill obligations and conduct business.

- Capacity: Assessment. This is focused on how the distribution of capital is placed by these entrepreneurs, so that all existing sources can run effectively.

- Collateral: Collateral for the approval of credit extension which is a means of safeguarding the risks that may occur due to default of the debtor in the future.

The use of these different principles makes the P2P Lending system tend to be faster than the existing credit system in banking in general. However, the use of guarantees in P2P Lending

16 "Fungsi dan Manfaat P2P Lending". diakses pada https:// koinworks.com/blog/keuntungan-p2p-lending/, tanggal 13 April 2019, pada pukul 12.27 WIB.

${ }^{17}$ Trisadini Prasastinah Usanti dan Abd. Shomad. (2015). Hukum Perbankan. Surabaya: Lutfansah Mediatama, h. 112. 
services is only done by showing an invoice. Because P2P Lending is here to help small and medium businesses (MSMEs) that do not have large guarantees.

3. P2P Lending Platform Online, Fintech di Indonesia.

4. Geographical Market, P2P Lending, especially Investors, has only been applied and only reaches within Indonesian territory. ${ }^{18}$

5. Supervision, The form of supervision carried out by OJK on technology-based lending and borrowing services is regulated in Article 6 POJK No. 77/2016 jo Article 55 of the OJK Law.

a. Electronic Commerce (Electronic Commerce), as part of Electronic Business (business conducted using electronic transmission), by experts and business people, the definition is tried. In general e-commerce can be defined as all forms of trade transactions/trade in goods or services (trade of goods and services) using electronic media. It is clear, apart from those mentioned above, that these commercial activities are part of business activities. Here are some characteristics of E-Commerce;

b. a Transaction without borders, Before the internet era, geographical boundaries often became a barrier for a business to go international, so that only large capitalized companies could market their products abroad. Today, with internet small and medium entrepreneurs can market their products internationally, simply by creating a website or by placing advertisements on internet sites without limitation time (24 hours), and of course customers from all over the world can access the site and do transactions on line;

c. Anonymous transactions, sellers and buyers in transactions over the internet do not have to meet each other face to face. The seller does not need the name of the buyer as long as the payment has been authorized by the payment system service provider specified, generally by credit card, and even now

${ }^{18}$ Investree. (9 Maret 2018). Aturan Dasar Penjelasan Pembagian Wilayah Pada Investree. Jakarta: Investree. transactions can be done virtually through Paypal or similar payment gateways;

d. Digital and Non-Digital Products, digital products such as computer software, music and other digital products, can be marketed through the internet by downloading electronically. In its development objects offered through the internet also include other necessities.

e. Intangible goods products, Many companies engaged in e-commerce offer intangible goods such as data, software and ideas that are sold through the internet. The implementation of e-commerce in the industrial world, the longer the wider not only provides convenience in business, but also changes the atmosphere of competition to become increasingly dynamic and global. Technological development not only supports the smooth and sustainable business activities, but also creates new industries in business communication.

The application of e-commerce, has created a separate community called the Electronic Business Community (electronic business community). This community utilizes cyber space as a place to meet, communicate and coordinate intensively by utilizing the media and telecommunications infrastructure and information technology in carrying out its daily activities. As in traditional societies, meetings between various parties with various interests naturally have formed a separate market where meeting demand and supply. With the development of e-commerce technology, the transaction can be easily carried out, even though the two parties that transact are on different geographical sides.

In this modern era, the online business world is growing rapidly. Online business is any business activity carried out through the internet. One type of online business that is mostly done is the business of buying and selling goods/services online or e-commerce. As an online business entrepreneur, many offers are done through a variety of sales products in the form of goods or services through the online buying and selling application. Income that will be obtained is considered more promising. Online business is considered profitable because it is more flexible to do anywhere and anytime. 
The potential of an online business is very tempting. On the other hand, in maintaining this business, you must master internet marketing. Through internet marketing, you can do business marketing to the fullest. This might not be easy, given the high level of competition found in the online business world so that it will require a variety of telling strategies in marketing that will be done.

Becoming a citizen and your online business entrepreneur automatically becomes a taxpayer. You are required to pay tax on income earned. By regulation, there is no tax difference between e-commerce transactions and conventional trade because the status of the tax object is the same. In the Circular Letter Number SE-62 / PJ / 2013, it is stated that the transaction of goods and services trading electronically or e-commerce is the same as the transaction of other goods and services, but it is different in terms of the method or tool used to conduct the transaction.

The object of income tax is income itself that is obtained through online and offline transactions. The provision is that any additional income received by the Taxpayer, which adds to the wealth of the Taxpayer must be subject to income tax. Imposition of online sales tax liability is also equated with conventional buying and selling transactions, thus the tax provisions applicable to online businesses are no different from conventional businesses. Online businesses will be subject to Taxable Entrepreneurs (PKP), the obligation to pay taxes arises when they earn more than Rp.600,000,000 per year.

During this online business entrepreneurs have actually paid taxes. However, until now, online business entrepreneurs are still making tax payments with a self-assessment scheme, which is a tax collection system that gives trust to Taxpayers (WP) independently to calculate, pay, and report themselves the amount of tax that should be owed based on regulations taxation. With the selfassessment system, all this time online business entrepreneurs have reported their profit through the Annual Income Tax Return (SPT). However, there are still many online business entrepreneurs who are less disciplined in reporting taxes. Therefore, the government continues to draft new regulations related to this online business tax.
The new scheme that will be applied to online business tax is still based on self-assessment. It's just that, later the government will involve a third party. These third parties will collect or deduct income tax and VAT from online businesses. It is expected that the tax imposition process can take place more easily. Tax payments are made monthly with a mechanism of withholding or collection by third parties. Third parties are appointed based on taxation provisions to cut or collect taxes and deposit to the state treasury.

Obligations carried out by the market place owner and the traders in which:

1. Notifying the Taxpayer Identification Number to the marketplace platform provider (Article 3 paragraph (6) PMK 210/PMK.010/2018).

2. If you do not have an NPWP, you can choose to (1) register to obtain an NPWP, or (2) notify the Population Registration Number to the marketplace platform provider (Article 3 paragraph (7) PMK 210/PMK.010/2018).

3. Carry out PPh-related obligations in accordance with applicable regulations, such as paying the final tax at a rate of $0.5 \%$ of turnover in the event that the turnover does not exceed Rp4.8 billion in a year.

4. Inaugurated as a Taxable Entrepreneur in terms of turnover exceeding Rp. 4.8 billion in a year, and carrying out VAT-related obligations in accordance with applicable regulations.

\section{AWARENESS TO PAYTAX FOR E-COMMERCE BUSINESS IN INDONESIA}

The bank until now stands as the economic driving agency in Indonesia which holds the most important and most important role in social life. It is regulated in Article 4 of the Banking Act, namely that banks in Indonesia aim to support the implementation of national development in order to increase equality and economic growth and national stability. towards improving people's welfare.

One of them leads to Technology-based Money Lending and Borrowing Services. Based on Article 6 of the banking law, business activities conducted by banks include commercial bank businesses, among others:

a. Collecting funds from the public in the form of deposits in the form of time deposits, certificates of deposit, savings and or other forms equivalent. 
b. Give credit.

c. Issued a credentials letter.

d. Buy and sell or guarantee your own risk or interests at the behest of its customers:

1. Notes;

2. Debt recognition documents and other commercial paper, which have a validity period not longer than the usual practice in trading the said letter;

3. State treasury papers and government guarantees;

4. Bank Indonesia Certificates;

5. Bonds;

6. Commercial papers with a term of up to 1 year;

7. Other security instruments which have a period of up to one year.

Lending by banks is one step that contains many risks that arise. The risk that is very often encountered is bad credit or non-performing loans. In providing credit the Banking Act limits the amount of credit that can be given by banks. Based on Article 11 paragraph 2 of the Banking Act, the maximum lending limit is a maximum of $30 \%$ (thirty percent) of bank capital in accordance with the provisions stipulated by Bank Indonesia. For special parties related to banks, the maximum lending limit may not exceed $10 \%$ of bank capital as stipulated in paragraph (4):

a. Shareholders who own $10 \%$ (ten percent) or more of the paid up capital of the bank;

b. Board of Commissioners member;

c. Members of the board of directors;

d. Family of parties as referred to in letter a, letter $\mathrm{b}$ and letter $\mathrm{c}$;

e. Other bank officials; and

f. Companies in which there are interests of the parties as meant in letter $a$, letter $b$ and letter $c$, letter d, letter e.

There are also characteristics of the Credit Online System that are compared with P2P Lending Services, among others:

1. Legal relationship

Instant funds are a credit product from Bank Danamon. Dana Instant moves in an online system that is likened to P2P Lending. But there is a slight difference with P2P Lending, in this case the legal relationship. Instant funds do not need to enter into a prior cooperation agreement with any bank because Bank Danamon is the only bank in the process of raising funds. So that this Bank Danamon has the nature of a single bank. The nature of a single bank, Bank Danamon, in this case can directly raise funds and can distribute them to the public.

So based on the explanation, the Legal Relationship between Instant Funds and Bank Danamon is one of the fulfillment of elements from Intermediary Institutions as a function of banking. Namely Bank Danamon as entitled to raise funds directly through the Instant Fund service and can also directly channel funds to the public without having to cooperate with any party. So in the Online Credit System Service which is likened to P2P Lending which places that the Intermediary Institution applies in the process of granting credit in the Instant Fund. ${ }^{19}$

2. Functions

National banking has a function in national economic life as a Financial Intermediary. So the bank has functions, among others: ${ }^{20}$

a. Agent of trust, is a trust that is owned by the public to the bank in depositing its funds, both for savings and investment. This community trust is the basic capital for banks in carrying out banking activities. With this element of trust, the community believes that money will not be misused by banks, the money they give will be well managed and they are sure that whatever will happen in the future, banks will be fully responsible for it. ${ }^{21}$

b. Agent of Development, a bank exists as a driving force for a nation's economy. Both in the monetary sector and in the real system, the two are clearly inseparable. This real sector cannot perform well if the monetary sector does not work well. The activities that can be carried out by banks as agents of development here are banks as institutions that collect and flow funds so that banks

\footnotetext{
${ }^{19}$ Airin. op.cit., h. 26.

${ }^{20}$ Sigit Tridaru. (2006). Bank dan Lembaga Keuangan Lain. Jakarta: Salemba Empat, h. 75.

${ }^{21}$ Etty Mulyati. (2015). Kredit Perbankan Dalam Aspek Hukum dan Pengembanagan Usaha Mikro Kecil Dalam Pembangunan Perekonomian Indonesia. Bandung: Refika Indatama, h. 63.
} 
are present as institutions to make financial investments in the monetary sector that are driving all progress in the real sector in this country. The smooth running of investment, distribution and consumption activities is none other than one of the development activities in the nation's economy. ${ }^{22}$

c. Agent of Service, banks in carrying out banking activities and a series of business activities carried out can also provide other offering services to the public. Other services offered in the form of money transfer services, safekeeping of valuables, providing bank guarantees, and billing settlement. ${ }^{23}$

3. The platforms

The Online Credit System is a new step from conventional banking to compete with Fintech Services today. Fintech is developing through an online platform that aims to facilitate the community in funding and time efficiency. So in this online credit system, the Bank, in this case Bank Danamon, uses an online platform or the same place as P2P Lending to compete with Fintech services that are currently developing. Geographical Market, Credit Online System is only valid in Indonesia. ${ }^{24}$

\section{Supervision}

The same form of supervision also applies to the Credit Online System conducted by the OJK for technology-based lending and borrowing services stipulated in Article 6 in conjunction with Article 55 of the OJK Law.

Banks as a means for payment of electronic commerce, also have an obligation to make and socialize tax payments. More and more business relationships are carried out by the community, making one of its business actors taxed as a civic duty. Taxes are dues to the state (which can be forced) owed by those who are obliged to pay according to the regulations, with no achievements, which can be appointed and whose use is to finance public expenditures related to the state's duty to administer

\footnotetext{
22 ibid., h. 65.

23 ibid.

${ }^{24}$ Wawancara dengan Manajer Kredit Bank Danamon Surabaya, Surabaya, 9 Agustus 2018.
}

the government. ${ }^{25}$ Taxpayers are individuals or entities that according to the provisions of tax legislation are determined to carry out tax obligations, including certain tax collectors or tax cutters. Personal Obligation is every individual who has income above non-taxable income. The imposition of tax by the government in the form of tax collection on taxpayers is in essence a manifestation of the dedication of the obligation and the role of the taxpayer to directly and jointly carry out the tax obligations required for state financing and national development. ${ }^{26}$

Awareness of taxpayers to pay taxes so that government revenue can run well, it must be examined and billing taxpayers and avoid tax evasion that is rife in this country and public confidence to pay taxes has also increased. The government must also do a lot of socialization so that taxpayers can report taxes that should be given to the government without reducing or saving for themselves.

Tax collection has been regulated in the legislation in article 23A of the 1945 Constitution (the 1945 Constitution which was amended for the third time in 2001) states "Taxes and other compulsory levies for state purposes are regulated by law". Tax collection is not an easy task, in addition to the active participation of tax officials, public awareness is also required to pay taxes. In general, people (taxpayers) tend to avoid tax payments. This trend occurs because of the low level of public awareness and lack of public knowledge and understanding of tax regulations.

Obedience means obeying or obeying teachings or rules. So taxpayer compliance can be interpreted as subject to, obey and obey taxpayers in carrying out their taxation rights and obligations in accordance with applicable tax laws. Tax compliance can be defined as a condition where taxpayers fulfill all tax obligations and implement tax rights. Tax compliance as a condition where taxpayers fulfill all tax obligations and carry out their tax rights. ${ }^{27}$

From the above statement, it can be concluded that taxpayer compliance is a condition where taxpayers fulfill all tax obligations and implement tax rights. The attitude of taxpayers who have a

${ }^{25}$ PJ. A. Adriani. (2014). Pajak dan Pembangunan. Jakarta: UI-Press, h. 5.

${ }^{26}$ Mohammad Zain. (2008). Manajemen Perpajakan. Jakarta: Salemba Empat, h. 43.

${ }^{27}$ Abdul Rahman. op.cit., h. 32. 
sense of responsibility as citizens is not just afraid of sanctions from the applicable tax law, as well as taxpayers who submit their tax returns in a timely manner. In general, tax compliance is divided into two:

1. Formal Compliance is a situation where taxpayers fulfill tax obligations formally in accordance with the provisions of tax laws.

2. Material compliance Material compliance is a condition where the taxpayer substantively fulfills all material tax provisions.

Then it can be concluded that the form of taxpayer compliance is divided into two namely formal compliance and material compliance, both of which demand that taxpayers meet tax obligations in accordance with applicable laws.

Factors that affect taxpayer compliance, i.e..$^{28}$

1. Effect of Morality Motivation that arises in taxpayers, on a willingness, confidence to participate to the state by paying taxes which can be expressed as an attitude of tax compliance. Morality is one aspect of tax compliance, some of which underlie morality factors, namely demographic, national pride, citizen participation, trust, regional autonomy, economic conditions, taxation system, defference factors.

2. Cultural Influence The concept of Tax Culture is the overall formal and informal interaction within an institution that connects the national taxation system with the Taxpayer which has historically been attached to the national culture, including the dependencies and ties that are formed as a result of continuous interaction.

3. Influence of Indonesian Religion, there are various beliefs that are held, it does not mean differences in beliefs do not make people divide, tolerance between religious communities, and not related to tax collection, from the religion they hold.

4. Effects of Education The higher a person's education, the higher the awareness of people to pay taxes, with higher education will understand the benefits of taxation and the acquisition of taxes used for development and welfare of the people.

\footnotetext{
${ }^{28}$ Widi Widodo. (2010). Moralitas, Budaya dan Kepatuhan
} Pajak. Bandung: Alfabeta, h. 8.
From the above understanding it can be concluded that taxpayer compliance is:

- Taxpayer must register himself to be able to fulfill his obligations and maintain order tax payments.

- Taxpayers must pay their tax obligations at the Tax Office in their respective regions, through other parties or through the Taxpayers themselves.

- Taxpayers must submit a Notification Letter that has been registered with the Tax Office that is equipped with financial statements.

- Tax awareness is a taxpayer who is willing without coercion to pay tax obligations. Taxpayers who know how to tax regulations, implement tax provisions correctly, and are voluntary. Taxpayers who are aware of their taxes will not violate applicable tax regulations, taxpayers also calculate their taxes correctly, and will pay their tax due. Awareness is a state of knowing or understanding, while taxation is a matter of taxation. So that tax awareness is the state of knowing or understanding about tax. Positive assessment of taxpayers on the implementation of state functions by the government will move the public to comply with their obligations to pay taxes, therefore awareness of taxpayers about taxation is very necessary to improve taxpayer compliance. Taxpayer awareness is the behavior of taxpayers in the form of views or perceptions that involve beliefs, knowledge and reasoning as well as a tendency to act in accordance with the stimulus provided by the applicable taxation system and provisions.

Thus it can be concluded that taxpayer awareness is a condition where taxpayers know and understand tax matters. Taxpayer awareness is needed, if the taxpayer is aware of paying taxes, the taxpayer's compliance will be fulfilled, so that tax payments will continue to increase and no more taxpayers are reluctant to pay taxes.

As one of the efforts to improve e-commerce company tax compliance, the Government through the Ministry of Finance plans to require online merchants to have a Taxpayer Identification Number (NPWP). This will be done gradually starting in 2018. This regulation is part of efforts to increase revenue and increase compliance in the fast-growing e-commerce 
industry. The Finance Ministry's Director General of Tax said that there are several e-commerce companies that will require sellers to show their NPWP identification numbers as a condition for operating on their platforms. This e-commerce platform will then submit monthly transaction reports to the Government. The pilot e-commerce companies are Tokopedia and Bukalapak. The collaboration with the two e-commerce platforms was carried out by the Government as a socialization of the obligation to have a TIN for SMEs who sell online. The next step is to increase compliance. This stage will be carried out cautiously because of the large number of online sellers so that there are few difficulties in tracking.

The obligation to pay taxes is done as one of the country's most widely earned income. E-commerce businesses are currently used as a valid taxpayer, because online transactions have been carried out in Indonesia. Businesses that carry out trading activities of goods and services through online retail, classified ads, daily deals, and social media must comply with the provisions related to VAT, PPnBM, and PPh in accordance with applicable regulations. This regulation will be effective on April 1, 2019.

The Directorate General of Taxes will carry out socialization to e-commerce actors, including marketplace platform providers and traders who use the platform. So in this case not only imposed by start-up business owners, but also traders who enter their merchandise into this place of business. For example online entrepreneurs who entrust their merchandise to be sold to certain market places.

Given the tax as a source of state revenue, e-commerce company tax must indeed be imposed considering e-commerce transactions that reach trillions of Rupiahs. Withdrawal of tax from e-commerce transactions aims to implement justice for all taxpayers, both conventional and e-commerce. Basically, taxpayers of e-commerce and conventional business do not differ. Both the seller and the buyer can be taxed in accordance with the provisions of the applicable tax laws. E-commerce actors must calculate their taxes, make deposits and report them, and make e-invoices if they have been confirmed as Taxable Entrepreneurs.

The Directorate General of Taxes will collect taxes for taxpayers of online business entrepreneurs who do not carry out the obligation to pay taxes, the billing action is carried out if the taxpayer does not pay the tax due in accordance with the period specified in the Tax Collection Letter (STP), or the Tax Assessment Letter (SKP), Correction Decree, Objection Decision, Appeal Decision. The billing process starts with a Letter of Reprimand and continues with a Forced Letter. If the taxpayer still does not pay his tax bill, confiscation and auction can be carried out on the taxpayer's property to pay tax that has not/has not been paid. The Directorate General of Taxes (DGT) may impose tax penalties on taxpayers who are not cooperative in paying their tax debt. If you have been hit by an obligation but deliberately did not register yourself as a Taxable Entrepreneur, you will be sentenced to a minimum of 6 months and a maximum of 6 years. While fines of at least 2 times the amount of tax payable that is not or not paid and at most 4 times the amount of tax payable that is not or underpaid according to Article 39 paragraph (1) of Law no. 28 of 2007 concerning the Third Amendment to Law No. 6 of 1983 concerning General Provisions and Tax Procedures.

\section{CLOSING}

\section{Conclusion}

Regulation of the Minister of Finance Number 210/PMK.010/2018 concerning Tax Treatment of Trading Transactions through the Electronic System is stated, Providers of Marketplace Platforms are required to have a Taxpayer Identification Number (NPWP) and must be confirmed as PKP (Taxable Entrepreneur). The obligation to be confirmed as PKP as intended, according to this PMK, also applies to Marketplace Platform Providers, even though it meets the criteria of being a small entrepreneur as stipulated in the Minister of Finance Regulation concerning the limits of Value Added Tax small entrepreneurs. In addition, the Trader or Service Provider must notify the NPWP to the Marketplace Platform Provider.

Most Indonesians do not yet have a high enough level of awareness in reporting compliance and paying taxes. In fact, many conveniences to report and pay taxes have now been offered. Various financial technologies that are increasingly developing in this digitalization era make it even easier for you in financial matters. You can do this 
through the Directorate General of Tax's website (DGT) or through a number of application service providers (ASPs). This application can encourage the awareness of entrepreneurs, especially e-commerce entrepreneurs to pay taxes as an obligation as a good citizen.

\section{Recommendation}

The government must disseminate information on e-commerce entrepreneurs in the imposition of this tax. If taxation from e-commerce transactions is not enforced, the result will not be the implementation of the principle of justice in law enforcement. The bad thing that will certainly happen is of course the competition between entrepreneurs becomes unbalanced because of the uneven tax burden between offline store entrepreneurs and online entrepreneurs. Therefore, e-commerce tax can be said as a means of equal distribution of people's income.

The government must implement the regulation strictly, so that all e-commerce entrepreneurs can carry out their obligations in paying taxes. This tax payment is not selectively made, both market place owners and market place users for selling places. Taxes can be carried out independently by each taxpayer, or tax payments can be made directly at the time of the sale and purchase transaction is done through cutting the balance in the account at the time of registration as a trader at the market place.

\section{BIBLIOGRAPHY}

\section{Laws:}

UUD 1945.

Peraturan Menteri Keuangan (PMK) No. 210/ PMK.010/2018 atas Perlakuan Perpajakan atas Transaksi Perdagangan melalui Sistem Elektronik (e-Commerce).

POJK No. 77/POJK.01/2016 concerning Information Technology Based Money Lending and Borrowing Services.

OJK Law No. 28 of 2007 concerning the Third Amendment to Law No. 6 of 1983 concerning General Provisions and Tax Procedures.

Bank Indonesia Regulation Number 19/12/PBI/2017 concerning The Implementation of Financial Technology.

\section{Books:}

Abdul Halim Barkatullah. (2006). Bisnis E-Commerce. Yogyakarta: Pustaka Pelajar.

Andy Hartanto. (2015). Hukum Jaminan dan Kepailitan. Surabaya: Laksbang Justitia.

Etty Mulyati. (2015). Kredit Perbankan Dalam Aspek Hukum dan Pengembanagan Usaha Mikro Kecil Dalam Pembangunan Perekonomian Indonesia. Bandung: Refika Indatama.

Investree. (9 Maret 2018). Aturan Dasar Penjelasan Pembagian Wilayah Pada Investree. Jakarta: Investree.

Mohammad Zain. (2008). Manajemen Perpajakan. Jakarta: Salemba Empat.

Mudakir Iskandarsyah. (2018). Hukum Bisnis Online Era Digital. Jakarta Barat: Campustaka.

PJ. A. Adriani. (2014). Pajak dan Pembangunan. Jakarta: UI-Press.

Purbo Onno W. dan Aang Arif Wahyudi. (2001). Mengenal E-Commerce. Jakarta: Elex Media Komputindo.

Sigit Tridaru. (2006). Bank dan Lembaga Keuangan Lain. Jakarta: Salemba Empat.

Trisadini Prasastinah Usanti dan Abd. Shomad. (2015). Hukum Perbankan. Surabaya: Lutfansah Mediatama.

Widi Widodo. (2010). Moralitas, Budaya dan Kepatuhan Pajak. Bandung: Alfabeta.

\section{Journals:}

Fani Martiawan Kumara Putra. (2019). "Pendaftaran Online Jaminan Fidusia Sebagai Suatu Fasilitas Kredit Dengan Potensi Lemahnya Perlindungan Kreditor". Perspektif, Vol. 24 No. 2 Tahun 2019, h. 96.

\section{Website and Other:}

"E-Commerce in Asia: Bracing for Digital Disruption", diakses melalui https://www. dbs.com/spark/index/id_id/dbs-yes-asset/ files/(Riset\%201)\%20Mendorong\%20 Pengembangan\%20Ekonomi\%20Digital\%20 di\%20Luar\%20Jawa, dikutip pada tanggal 18 Februari 2019, pukul 06.02 WIB.

"Fintech Terdaftar", diakses pada www.ojk.go.id, pada 16 Februari 2019 pukul 17.28 WIB.

"Fungsi dan Manfaat P2P Lending". diakses pada https://koinworks.com/blog/keuntungan-p2p- 
lending/, tanggal 13 April 2019, pukul 12.27 WIB.

"Pangsa Pasar Fintech". www.cnbcindonesia. com (online). 3 Desember 2018. https://www.cnbcindonesia.com/ fintech/20180113160215-40-1387/milenialpasar-terbesar-fintech.

Airin. (2017). "Perbedaan Karakteristik Layanan Pinjam Meminjam Uang Berbasis Teknologi Informasi (Peer to Peer Lending) denganPerbankan". Skripsi. Surabaya: Program Sarjana, Universitas Airlangga.
Diakses melalui https://www.finansialku.com/ definisi-fintech-adalah/, pada tanggal 25 Februari 2019, Pukul 16.20 WIB.

Keuntungan dan Kerugian Peer To Peer Lending, Diakses melalui https://www.kompasiana.com/ udyvallentine 7708/5b4daeab5a676f1d490f6d02/ peer-to-peer-p2p-lending?page $=$ all, pada tanggal 25 Februari 2019, pada pukul 16.34 WIB.

Wawancara dengan Manajer Kredit Bank Danamon Surabaya, 9 Agustus 2018. 